\title{
Analysis of Shear Behavior and Fracture Characteristics of Plywood in Cryogenic Environment
}

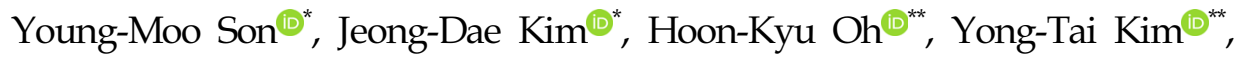 \\ Seong-Bo Park ${ }^{* * *}$ and Jae-Myung Lee ${ }^{*}$ \\ *Department of Naval Architecture and Ocean Engineering, Pusan National University, Busan, Korea \\ ${ }^{* *}$ Research Institute, Hyundai Heavy Industries Co. Ltd, Seoul, Korea

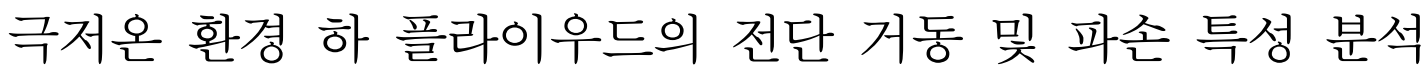

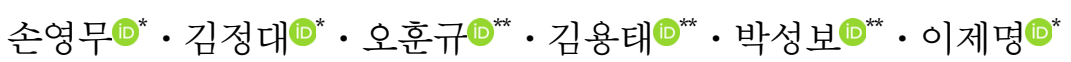 \\ "부산대학교 조선해양공학과 \\ *현대중공업(주) 선박연구소
}

KEY WORDS: Liquefied gas storage tank 액화가스 저장탱크, Cryogenic 극저온, Plywood 플라이우드, Shear Behavior 전단거동, Fracture characteristic 파손특성

\begin{abstract}
Plywood is a laminated wood material where alternating layers are perpendicular to each other. It is used in a liquefied natural gas (LNG) carrier for an insulation system because it has excellent durability, a light weight, and high stiffness. An LNG cargo containment system (LNG CCS) is subjected to loads from gravity, sloshing impact, hydrostatic pressure, and thermal expansion. Shear forces are applied to an LNG CCS locally by these loads. For these reasons, the materials in an LNG CCS must have good mechanical performance. This study evaluated the shear behavior of plywood. This evaluation was conducted from room temperature $\left(25^{\circ} \mathrm{C}\right)$ to cryogenic temperature $\left(-163{ }^{\circ} \mathrm{C}\right)$, which is the actual operating environment of an LNG storage tank. Based on the plywood used in an LNG storage tank, a shear test was conducted on specimens with thicknesses of 9 mm and $12 \mathrm{~mm}$. Analyses were performed on how the temperature and thickness of the plywood affected the shear strength. Regardless of the thickness, the strength increased as the temperature decreased. The $9 \mathrm{~mm}$ thick plywood had greater strength than the $12 \mathrm{~mm}$ thick specimen, and this tendency became clearer as the temperature decreased.
\end{abstract}

\section{1. 서 론}

최근 조선해양산업 분야에서 국제해사기구에서의 $\mathrm{NOx}$ 와 SOx 와 같은 대기오염 배출가스 규제로 인하여 친환경 에너지인 액 화천연가스(Liquefied natural gas, LNG)를 연료로 사용하기 위해 활발하게 움직이고 있다. 이로 인하여 액화천연가스 추진선에 대한 연구와 개발이 지속되고 있으며, 천연가스 운반선의 수요 역시 급격하게 증가하고 있다. 천연가스 운반선은 동일한 공간 내에 더 많은 천연가스를 적재하기 위해 압력 $0.1 \mathrm{MPa}$ 에서 -16 $3{ }^{\circ} \mathrm{C}$ 의 온도로 액화시켜 부피를 $1 / 600$ 로 줄여 효율적으로 저장 및 운송한다. 이러한 $\mathrm{LNG}$ 화물창 내의 극저온 환경 유지를 위 해 LNG CCS(Cargo containment system)를 구비하여 기화로 인 한 손실량을 최소화 한다. 천연가스 운반선에서 기화량은 경제 적인 측면에서 가장 중요시 되는 부분으로 많은 연구가 진행되
고 있다. 현재 LNG CCS는 Membrane type이 널리 이용되고 있 으며, Mark-III type과 NO96 type을 주로 사용한다.

Mark-III type은 1차 방벽으로 오스테나이트 계 스텐리스 강 (SUS304L)을 주로 사용하고 열 변형 방지를 위해 주름진 형상 으로 제작하며, 단열패널로 강화 폴리우레탄 폼(Reinforced polyurethane foam, RPUF)과 플라이우드를 사용한다. 2차 방벽은 금속 복합시트로 구성 된 Triplex가 사용되고, 2차 방벽과 선체 사이에 단열 패널층, 마스틱이 위치한다. NO96은 1차 방벽, 2차 방벽, $36 \%$ 니켈합금강을 사용한 Invar steel과 함께 펄라이트로 구성된 플라이우드 단열패널로 이루어져있다.

최근 스테인리스 강과 폴리우레탄 폼과 같은 $\mathrm{LNG} \mathrm{CCS}$ 에 사 용되는 재료에 대해 많은 실험과 연구가 진행되고 있다(Park et al., 2016). LNG 화물저장탱크 내에서 유체의 정수압, 자중이 발 생하고, 또한 운송 과정에서 액체화물의 슬로싱(Sloshing)으로

Received 29 May 2019, revised 10 October 2019, accepted 16 October 2019

Corresponding author Jae-Myung Lee: +82-51-510-2342, jaemlee@pusan.ac.kr ORCID: http://orcid.org/0000-0002-8096-4306

(c) 2019, The Korean Society of Ocean Engineers

This is an open access article distributed under the terms of the creative commons attribution non-commercial license (http://creativecommons.org/licenses/by-nc/3.0) which permits unrestricted non-commercial use, distribution, and reproduction in any medium, provided the original work is properly cited. 


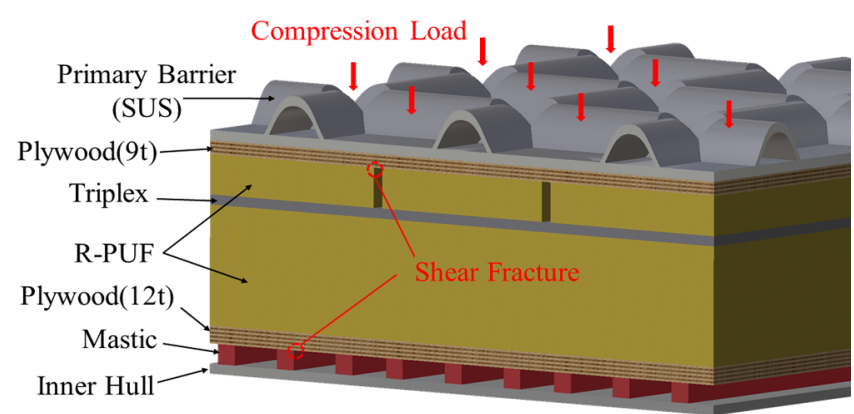

Fig. 1 LNG Mark-III type and location of shear fracture

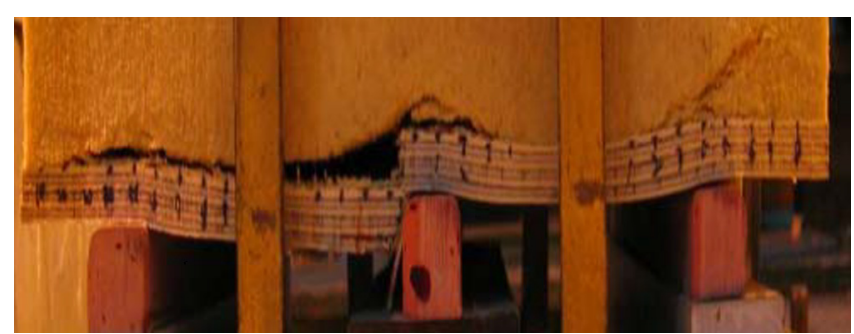

Fig. 2 Shear fracture of plywood in Mark-III type

인한 충격력이 단열시스템에 작용한다. 뿐만 아니라 $\mathrm{LNG}$ 저장용 기는 상온 $\left(25^{\circ} \mathrm{C}\right)$ 에서부터 극저온 $\left(-163^{\circ} \mathrm{C}\right)$ 까지 매우 넓은 온도범 위에서 운용이 되기 때문에 열에 의한 수축과 팽창이 반복해서 발생한다. 이 때, LNG 저장탱크를 구성하는 단열시스템의 각 재 료는 서로 다른 고유의 수축 및 팽창률을 가진다. 폴리우레탄 폼 의 경우 높은 수축 및 팽창률을 가지고(Yang et al., 2007), 플라이 우드와 스테인리스 강의 경우 폴리우레탄 폼에 비해 상대적으로 낮으며, Invar Steel의 경우 열 수축이 거의 발생을 하지 않는다 (Clark, 1968). 그 결과, 각 재료의 열 수축 및 팽창 차이로 하중이 발생한다. 이러한 환경에서 플라이우드에 압축 및 인장이 발생하 며, 순수 일축하중 외에 전단하중 역시 동반하게 된다. 특히 Mark-III Type에서는 Fig. 1과 같이 마스틱과 접촉하는 부분에서 전단으로 인한 파손이 발생하게 되기 때문에 선급 규정에서 플라 이우드의 전단 파손에 대해서 명시하고 있다.

또한 NO96 type은 Plywood box를 사용하므로 파손에 대비한 강도 확보가 필수적이다(Park and Lee, 2018).

그러므로 플라이우드의 기계적 강도 평가는 필수적이고, 특히 극저온 환경 하 재료의 거동에 대한 분석이 진행되어야 한다. 플라이우드에 대한 연구 역시 진행된 바 있으나 극저온 환경에 서의 연구는 부족하며, 특히 극저온에서 전단성능에 대한 평가 는 진행된 바 없다. Fig. 2 는 실제 플라이우드가 전단력에 의해 파손이 발생한 것이다. 이러한 현상이 발생하기 때문에 전단파 손에 대한 평가가 필수적이며(Kuo et al., 2009), 본 연구에서 전 단성능 및 파손특성에 대한 분석을 진행하였다.

\section{2. 실 험}

\section{1 실험 대상 및 장비}

$\mathrm{LNG}$ 선박 운용 환경 하에서 플라이우드의 전단성능을 평가 하는 것이 본 연구의 목적이다. 플라이우드는 얇은 목재판을 나 뭇결의 방향이 각 층마다 직교가 되도록 $0^{\circ}$ 와 $90^{\circ}$ 로 접착제를

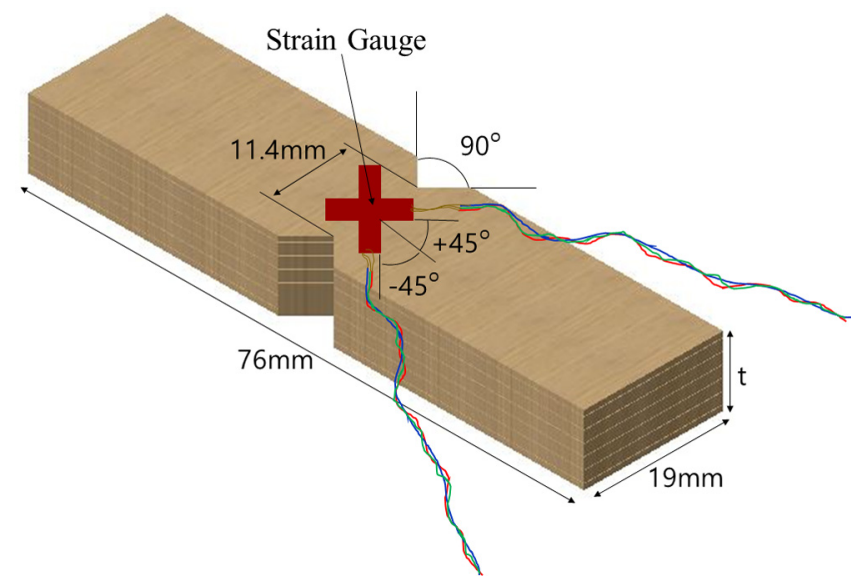

Fig. 3 Test specimen dimension and strain gauge position

이용하여 겹겹이 쌓아 올린 직교 이방성 경질재료이다. 이러한 재료 특성을 고려하여 복합재료 전단성능평가 표준시험 규격인 ASTM D5379-12를 바탕으로 시험편을 목재판으로부터 가공하 였다.

Fig. 3은 시험편 형상 및 규격을 도식화한 것이다. Mark-III type에서는 1 차 방벽과 마스틱에 각각 $9 \mathrm{~mm}$ 와 $12 \mathrm{~mm}$ 의 두께 플 라이우드를 부착한다. 이를 바탕으로 본 실험에서 역시 $9 \mathrm{~mm}$ 와 $12 \mathrm{~mm}$ 의 플라이우드에 대한 전단성능 및 파손특성을 분석하였 다. 본 연구에서는 Melamine-urea-formaldehyde(MUF) 접착제를 이용하여 목재판 각 층을 서로 직교하게 부착한 판을 이용하였 다. $9 \mathrm{~mm}$ 시편의 경우 총 7겹, $12 \mathrm{~mm}$ 시편의 경우 총 9 겹의 목재 판을 결합한 재료이다.

전단시험을 위해 복합재용 재료만능시험기(Universal testing machine, UTM)를 사용하였다. 실험 온도를 낮추기 위해서 액화 질소가스(LN2)를 사용하였으며, 온도 유지를 위해 극저온용 챔 버를 사용하였다. 표점에 대한 변형률을 측정하기 위해서 극저 온용 스트레인 게이지를 이용하였다.

\section{2 실험 조건}

본 연구는 LNG 저장용기 단열시스템에 사용되는 플라이우드 의 재료성능 평가로, 실제 운용되는 상온 $\left(25^{\circ} \mathrm{C}\right)$ 에서부터 극저온 $\left(-163^{\mathrm{C}}\right)$ 까지의 온도를 고려하여 실험을 진행하였다. 두 구간 사

Table 1 Shear test scenario

\begin{tabular}{ccc}
\hline \hline Material & Thickness $[\mathrm{mm}]$ & Temperature $\left[{ }^{\circ} \mathrm{C}\right]$ \\
\hline & & 25 \\
& 9 & -20 \\
& & -65 \\
& & -110 \\
& & -163 \\
\cline { 2 - 3 } & & 25 \\
& & -20 \\
& & -65 \\
& & -110 \\
& & -163 \\
\hline
\end{tabular}




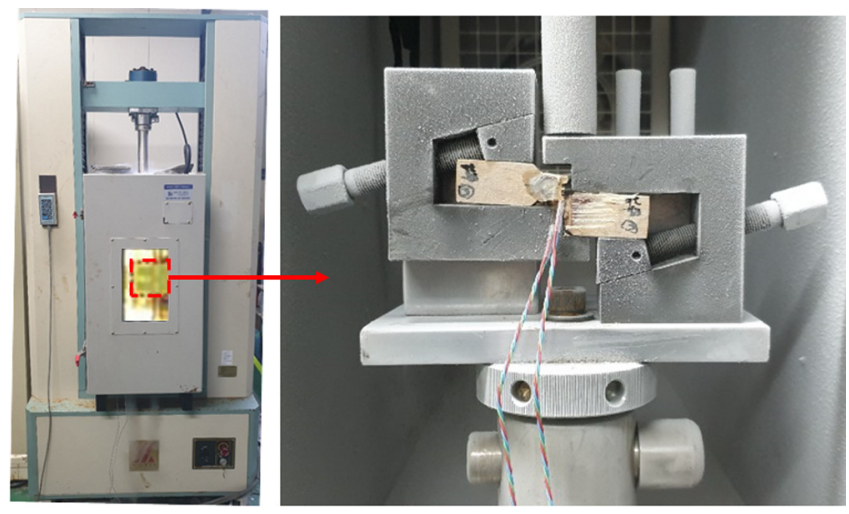

Fig. 4 Plywood shear specimen and experiment apparatus

이 $-20^{\circ} \mathrm{C}-65^{\circ} \mathrm{C}-110^{\circ} \mathrm{C}$ 대한 실험을 진행하여 온도에 따른 플라 이우드 거동을 분석하였다. 시편 두께는 $9 \mathrm{~mm}$,와 $12 \mathrm{~mm}$ 두 가지 로 선정하였으며, 이는 Mark-III type에서 각각 1차 방벽 및 마 스틱 부분에 접착되는 플라이우드 두께에 해당된다.

Fig. 4는 실제 플라이우드 전단시험 사진으로, 변형률 속도는 ASTM D5379-12를 바탕으로 UTM cross head 변위 속도 $2 \mathrm{~mm} / \mathrm{min}$ 에 대해 실험을 진행하였다. 시편자체 온도 역시 해당 실험 온도와 동일하게 하기위해 1 시간동안 충분한 예비 냉각을 진행하였다. 극저온용 스트레인게이지(CFLA-3-350-11)를 사용하 여 표점 변위를 측정하였고 $\mathrm{DAQ}(\mathrm{Data}$ acquisition) System에서 변형률 데이터를 추출하였다. 스트레인게이지는 Fig. 3과 같이 $+45^{\circ}$ 방향과 $-45^{\circ}$ 방향으로 서로 직교하게 부착을 하였고, 측정 된 변형률에 대한 절대값의 합이 최종 변형률이 된다. 각 실험 은 5 회 반복하였으며, 값이 가장 큰 경우와 작은 경우를 제외한 나머지 3 개의 결과에 대해서 평균을 구하였다.

\section{3. 실험 결과 및 분석}

\section{1 전단 실험 결과}

Fig. 5와 Fig. 6 은 $25^{\circ} \mathrm{C}$ 에서부터 $-163^{\circ} \mathrm{C}$ 까지 UTM을 사용하여 얻은 전단 시험 결과로, $9 \mathrm{t}$ 와 $12 \mathrm{t}$ 플라이우드의 변위에 따라 작 용한 하중 값을 나타낸 것이다. 하중이 최대인 지점이 항복점으 로, 항복전의 영역이 탄성구간, 항복점에서의 강도가 전단강도 이다. 항복점 이후 소성 구간으로, 플라이우드의 파손이 본격적 으로 발생을 한다. 파손으로 인하여 급격한 하중 저하가 발생하 고 완전한 파손에 이른다. 온도가 낮아질수록 항복에 이르는 변 위가 감소하고, 완전한 파손에 도달하는 변위 역시 감소하는 결 과를 얻었다. 저온으로 갈수록 각각의 섬유 층 사이에서 균열 및 박리현상이 발생하게 되는데, 이로 인하여 균열 진전이 급격 하게 발생하기 때문에 나타나는 현상의 결과로 판단된다(Choi and Sankar, 2007).

정확한 전단탄성계수 값을 구하기 위해서, 표점에서의 변위를 측정해야하기 때문에 스트레인 게이지를 사용하여 변형률 값을 얻었다. Fig. 3 과 같이 두 개의 스트레인 게이지를 $+45^{\circ}$ 방향과 $-45^{\circ}$ 방향으로 직교하게 부착하여 변형률 값을 측정하였다. $+45^{\circ}$ 방향의 스트레인 게이지는 수축으로 감소하는 변형률을 가지고, $-45^{\circ}$ 방향의 스트레인 게이지는 팽창으로 증가하는 변형률을 가 진다. 이를 고려하여 시편 표점에 대한 최종 변형률 $\left(\gamma_{i}\right)$ 은 두 스

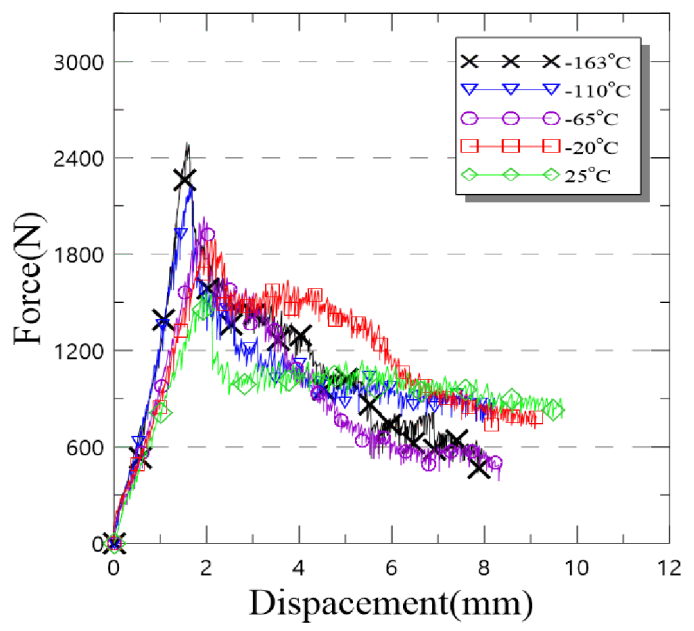

Fig. 5 Shear force-displacement behavior of 9t plywood

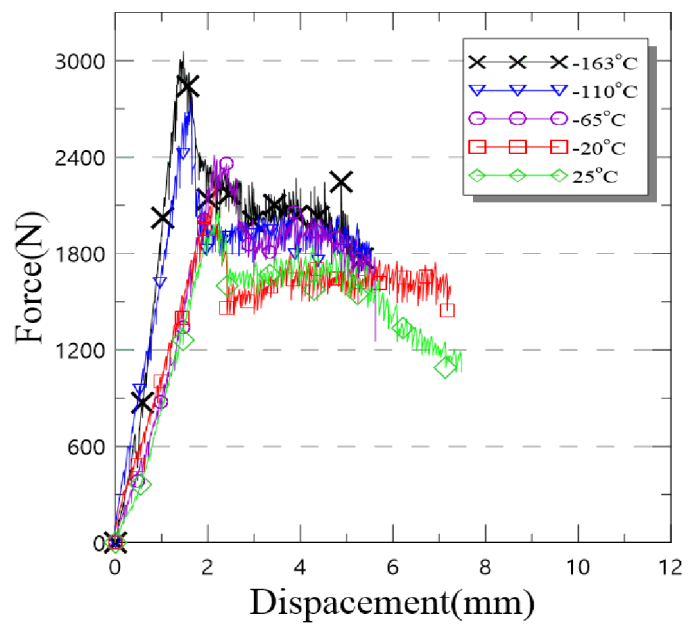

Fig. 6 Shear force-displacement behavior of $12 \mathrm{t}$ plywood

트레인 게이지 간의 절대값의 합으로, 아래와 같이 구할 수 있 다(Khashaba, 2004).

$$
\gamma_{i}=\left|\epsilon_{+45^{\circ}}\right|+\left|\epsilon_{-45^{\circ}}\right|
$$

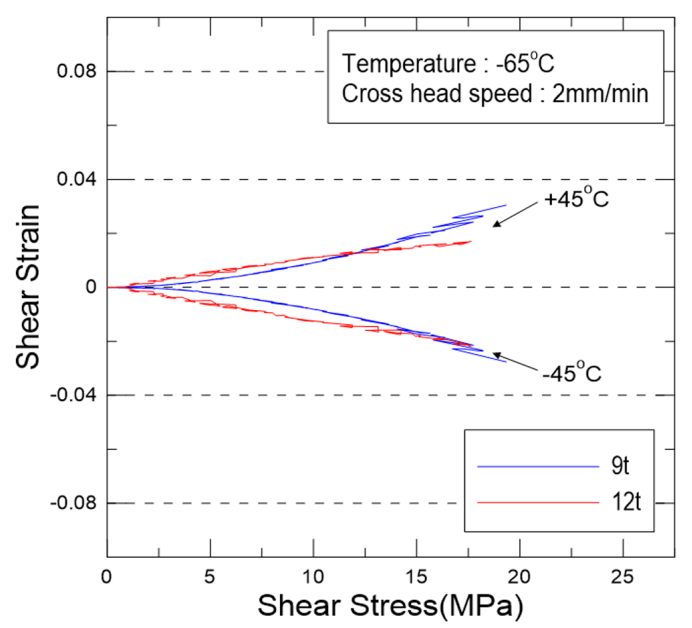

Fig. 7 Shear strain measured by $+45^{\circ}$ strain gauge and $-45^{\circ}$ strain gauge $\left(-65{ }^{\circ} \mathrm{C}\right)$ 


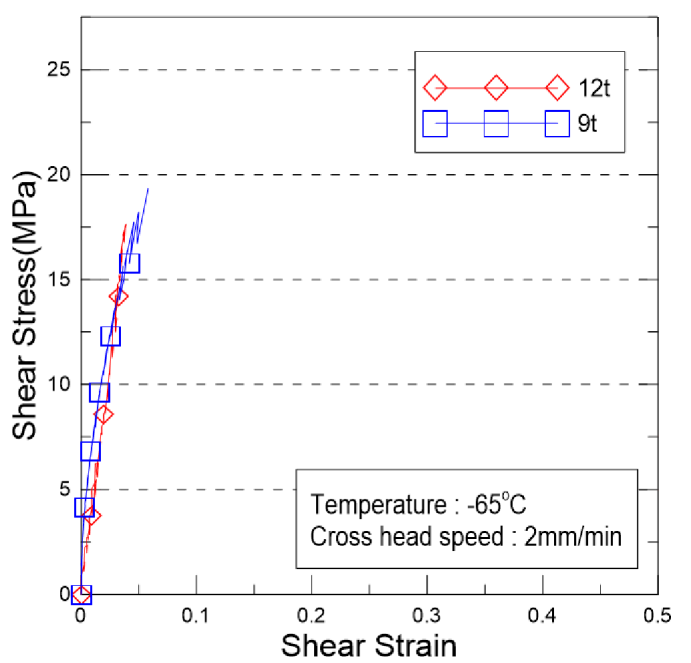

Fig. 8 Relation of strain-stress in elasticity region measured by strain gauge $\left(-65^{\circ} \mathrm{C}\right)$

스트레인 게이지에서 측정한 변형률과 UTM에서 플라이우드 에 작용한 하중값을 고려하여 탄성 구간에서의 선형 기울기를 구하여 탄성계수를 도출하였다.

Fig. 7은 동일시간에 탄성영역 내 UTM으로 측정한 하중을 통 해 구한 응력에 대한 두 개의 스트레인 게이지 측정값이며, Fig. 8은 두 스트레인 게이지에서 측정한 값으로 최종 응력-변형률 관계로 나타낸 것이다.

\section{2 결과 분석 및 파손특성}

Fig. 9는 스트레인 게이지를 통해 얻은 변위를 바탕으로 온도 에 따라 $9 \mathrm{~mm}, 12 \mathrm{~mm}$ 시편의 전단탄성계수를 나타낸 결과이다. 가장 큰 값과 작은 값을 제외한 3 번의 실험 결과에 대한 값을 평균값을 구하였다. 플라이우드의 두께와 상관없이 전단탄성계 수는 증가하는 결과를 얻었다. 탄성계수는 $9 \mathrm{t}$ 는 극저온에서 상 온에 비해 약 $140 \%$ 증가하였고, $12 \mathrm{t}$ 는 상온 대비 약 $115 \%$ 증가 하였다.

Fig. 10에서 전단강도 역시 온도가 낮아질수록 증가하는 결과 를 얻었다. $9 \mathrm{t}$ 의 경우 극저온에서 상온보다 약 $60 \%$ 향상하는 결 과를 얻었으며, $12 \mathrm{t}$ 의 경우 상온에서보다 약 $48 \%$ 향상하는 결과 를 얻었다.

저온으로 갈수록 분자와 원자 간의 결합을 이루는 힘이 증가 하게 된다(Barron, 1985). 또한 접착제의 강도 역시 저온으로 갈 수록 증가를 하게 되고(Kim et al., 2018), 플라이우드의 목재 내 부 셀이 함유하고 있는 수분이 저온으로 가면서 얼음 결정을 형성을 하며, 이로 인해 강도향상을 유발한다는 연구 결과들이 있다(Green et al., 1999). 이러한 요인들로 인해 본 플라이우드 실험에서 저온으로 갈수록 강도가 증가하는 결과를 유발한 것 으로 예상되며, 탄성계수는 탄성구간에서의 강도 대비 변형률 의 값이므로 강도 증가는 탄성계수 증가에도 영향을 준다. 또한 실험 결과를 보면 항복까지의 변형 값이 감소하는 결과가 나타 나는데 이 역시 탄성계수의 증가에 원인이 된다.

$-20^{\circ} \mathrm{C}-65^{\circ} \mathrm{C}$ 에서 탄성계수가 $9 \mathrm{~mm}$ 시편이 $12 \mathrm{~mm}$ 시편보다 더 낮은 값을 가지는 결과를 얻었다. 이는 다른 온도에서와 $12 \mathrm{~mm}$

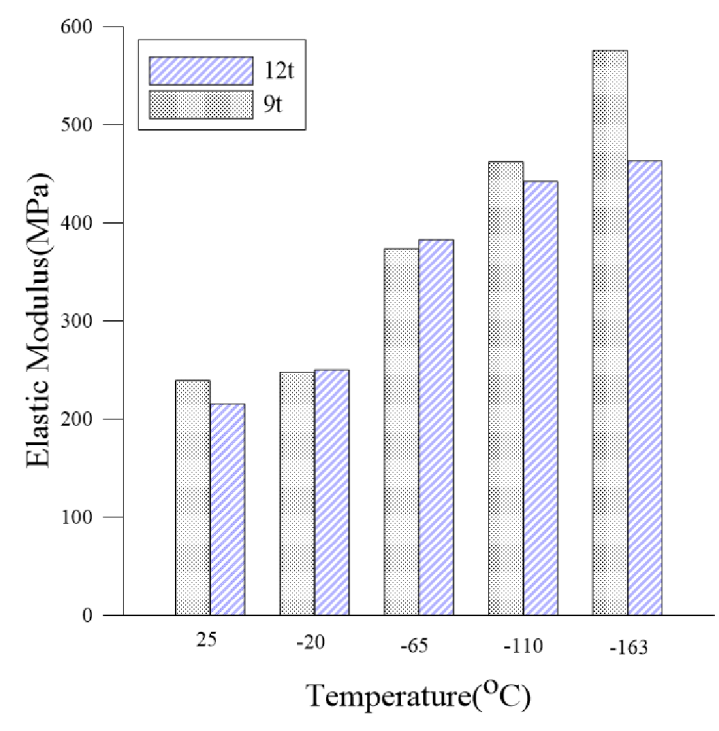

Fig. 9 Elastic modulus of plywood at each temperature

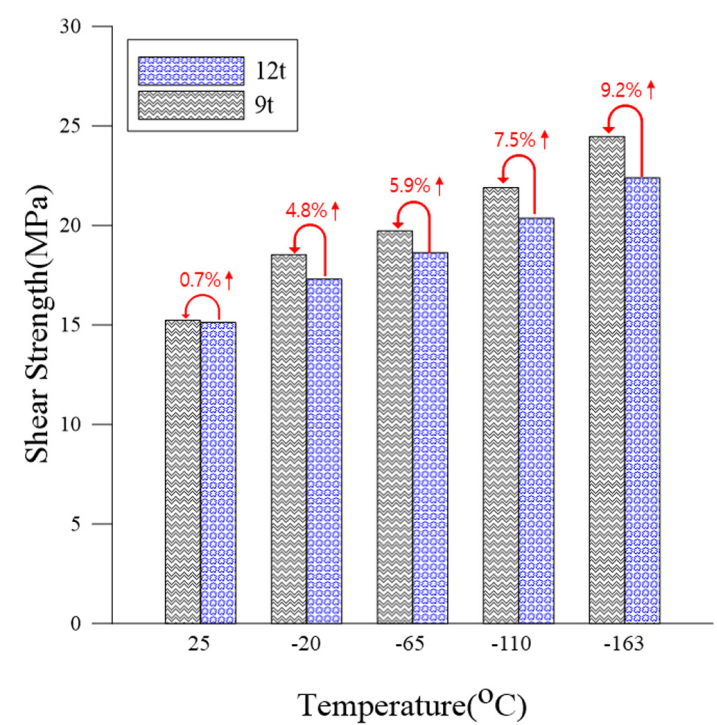

Fig. 10 Shear strength comparison between $9 t$ and $12 t$ at each temperature

시편이 더 낮은 값을 가지는 것과 상반되는 결과이다. 이는 수 분에 대한 영향으로 판단된다. 물의 어는점인 $0^{\circ} \mathrm{C}$ 이후로 플라이 우드 결정 내부의 수분이 결정화가 되고 이로 인해 적은 변위 에도 얼음 결정이 플라이우드 전체의 균열을 유발하여 파손을 일으키는 것으로 판단된다. $9 \mathrm{~mm}$ 시편보다 $12 \mathrm{~mm}$ 가 수분을 많이 가지고 있기 때문에 이러한 요인에 더 크게 작용하는 것으로 판단된다. $-110^{\circ} \mathrm{C}$ 가 넘어가는 극저온 구간에서는 수분의 영향뿐 만 아니라 MUF 접착제, 수축률 차이 영향을 급격하게 받으므 로 다시 $9 \mathrm{~mm}$ 시편에서 탄성계수가 높아지는 결과를 얻은 것으 로 판단된다.

Fig. 10은 9t, 12t 플라이우드의 전단강도를 각 온도별로 비교 를 한 것이다. 일반적으로 동일한 재료는 단면적과 상없이 동일 한 항복응력 값을 가진다. 그러나 본 연구에서는 전단강도가 모 든 온도에서 $9 \mathrm{t}$ 플라이우드가 $12 \mathrm{t}$ 플라이우드 보다 높은 결과 값을 얻었다. 이는 적층형 구조로 이루어진 플라이우드의 재료 


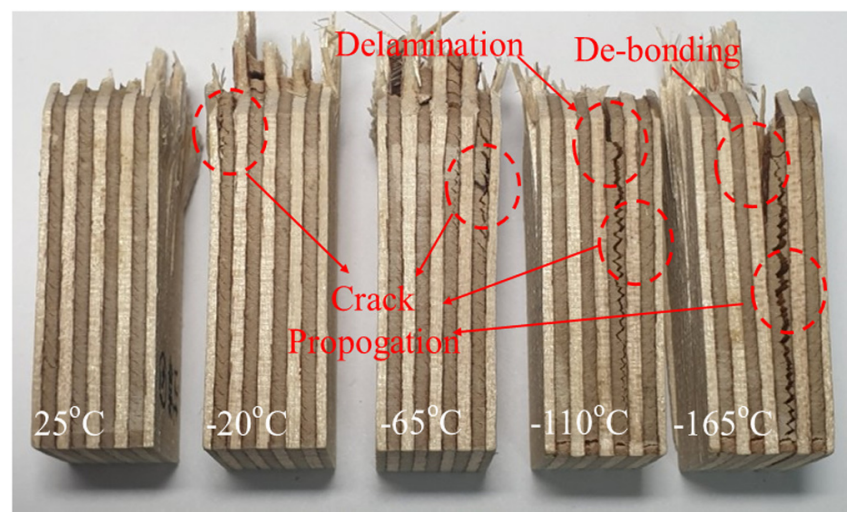

Fig. 11 Shear fracture of plywood at each temperature

특성에 의한 것이다. 단순 균일한 재료라면 두께의 영향이 없이 일정한 항복응력 값을 가지지만, 본 연구의 경우 각 층마다 전 단거동에 영향을 미치는 특성을 고려하여야 하며, 특히 각 층을 부착시키기 위해 사용한 접착제가 전체적인 플라이우드의 기계 적 강도에 큰 영향을 미치게 된다. 이러한 요인으로 플라이우드 는 두께가 두꺼워질수록 전단강도가 낮아지는 결과를 얻었다. 각 온도별 플라이우드의 두께에 따른 전단강도는 상온에서 $9 \mathrm{t}$ 가 $12 \mathrm{t}$ 보다 $0.7 \%$ 높은 결과를 얻었으며, 온도가 낮아질수록 점점 더 큰 차이가 발생을 하며, 극저온 $\left(-163^{\circ} \mathrm{C}\right)$ 에서는 $9.2 \%$ 차이가 발생을 하였다.

저온으로 갈수록 두께별 차이가 크게 발생하는데 가장 큰 요 인으로 MUF 접착제이다. MUF 접착제는 온도가 낮아질수록 접 착성능이 저하가 되어 하중을 받을 때 플라이우드의 각 층에서 de-bonding 현상을 유발하게 된다(Kim et al., 2018). 또한, 적층 된 구조의 플라이우드에서 층간 박리현상 역시 나타난다 (Arswendy and Moan, 2015). 더 많은 층으로 구성된 두께가 두 꺼운 플라이우드는 MUF의 de-bonding 현상과 층간 박리현상이 많이 발생하기 때문에(Kim et al., 2015) 더 큰 강도 저하가 발생 한다. 추가적으로, 온도가 낮아질수록 재료에 수축 현상이 발생 을 하는데, 각 재료는 고유의 수축률을 가진다. 목재와 MUF $\operatorname{Resin}$ 의 수축률 차이로 인하여 저온으로 갈수록 플라이우드 전 체 구조에 균열이 더 많이 발생하는 것으로 판단된다(Moubarik et al., 2009). Fig. 11은 온도에 별 플라이우드 전단 파손 형상으 로, 저온으로 갈수록 균열이 심하게 발생하여 파단 하는 결과를 확인할 수 있고, 저온으로 갈수록 두께에 의한 전단강도의 차이 가 크게 발생하는 결과를 발생시킨다.

\section{4. 결 론}

본 논문에서는 $\mathrm{LNG} \mathrm{CCS}$ 에 사용되는 플라이우드에 대한 전 단성능평가를 진행하였다. $\mathrm{LNG} \mathrm{CCS}$ 에 사용되는 $9 \mathrm{~mm}, 12 \mathrm{~mm}$ 두께에 대한 평가를 진행하였으며, 상온 $\left(25^{\circ} \mathrm{C}\right)$ 에서부터 $-20^{\circ} \mathrm{C}$, $-65^{\circ} \mathrm{C},-110^{\circ} \mathrm{C}$ 를 거쳐 실제 운용온도인 극저온 $\left(-163^{\circ} \mathrm{C}\right)$ 까지 전단 거동 평가를 진행하였고, 결과는 아래와 같다.

(1) 전단시험에서, 플라이우드는 온도가 낮을수록 항복에 이 르는 변형률이 감소를 하며, 전단강도와 탄성계수는 상승하였 다. 이는 분자와 원자 간의 결합력이 강해지고, 목재 섬유 내 수
분의 결빙, 접착제 자체의 강도 향상이 요인으로 작용한 결과로 판단된다.

(2) 플라이우드가 두꺼워질수록 전단강도의 값이 감소하는 경 향이 나타났다. 각 층을 접착하는 형태로 제작되는 재료 특성상 두꺼워질수록 더 많은 MUF 접착제를 사용하여 강도저하를 유 발한다. 또한 층간 박리현상으로 강도가 감소하는 결과를 유발 한다.

(3) 온도가 낮아질수록 $9 t$ 와 $12 t$ 의 전단강도의 차이가 크게 발 생하였다. 온도가 낮아지면서 MUF 접착제의 성능 저하로 층간 de-bonding현상이 발생한다. 층간 박리현상 역시 더 많이 발생 하며 각 재료의 다른 수축률로 인한 전체적인 플라이우드 구조 균열을 유발한다. 저온으로 갈수록 뚜렷한 현상이 발생하며, 두 꺼운 시편에서 더 많이 발생하기 때문에 두께에 따른 플라이우 드의 전단강도 차이는 온도가 낮아질수록 더 많이 발생한다.

본 실험에서 상온에서 극저온 환경까지의 온도별 플라이우드 의 전단거동과 파손특성을 분석하였고, 두께별로 전단강도가 다소 차이나는 결과를 얻었으며 파손특성을 바탕으로 원인을 분석하였다. 이를 바탕으로 $\mathrm{LNG} \mathrm{CCS}$ 를 포함한 플라이우드 구 조물 설계 시, 플라이우드의 재료특성을 고려하여 두께에 따른 성능의 변동성에 대한 평가 필요성을 제시한다.

향후 본 연구를 바탕으로 MUF 접착제의 저온 환경에서의 접 착강도, 접착 성능 특성에 대한 연구를 진행하고 플라이우드에 미치는 수분에 대한 추가 연구를 병행 후 이를 바탕으로 플라 이우드의 두께 및 온도에 따른 정확한 기계적 성능 및 파손특 성을 제시하여 정확한 $\mathrm{LNG} \mathrm{CCS}$ 설계에 적용할 것이다.

\section{후 기}

이 논문은 부산대학교 기본연구지원사업(2년)에 의하여 연구 되었음.

\section{References}

Arswendy, A., Moan, T., 2015. Strength and stiffness assesssment of an LNG containment system - Crushing and buckling failure analysis of plywood components. Engineering Failure Analysis, 48, 247-258.

Barron, R.F., 1985. Cryogenic systems. $2^{\text {nd }}$ Edition, Clarendon Press, Oxford.

Choi, S., Sankar, B.V., 2007. Fracture toughness of transverse cracks in graphite/epoxy laminates at cryogenic conditions. Composites Part B: Engineering, 38(2), 193-200.

Clark, A.F., 1968, Low temperature thermal expansion of some metallic alloys, Cryogenics, 8, 282-289.

Green, D.W., Evans, J.W., Logan, J.D., Nelson, W.J., 1999. Adjusting modulus of elasticity of lumber for changes in temperature. Wood Engineering, 49(10), 82-94.

Khashaba, U.A., 2004. In-plane shear properties of cross-ply composite laminates with different off-axis angles. Composite Structures, 65(2), 167-177. 
Kim, J.H., Choi, S.W., Park, D.H., Park, S.B., Kim, S.K., Park, K.J., Lee, J.M., 2018. Effects of cryogenic temperature on the mechanical and failure characteristics of melamine-ureaformaldehyde adhesive plywood. Cryogenics, 91, 36-46.

Kim, J.H., Park, D.H., Lee, C.S., Park, K.J., Lee, J.M., 2015. Effect of cryogenic thermal cycle and immersion on the mechanical characteristics of phenol-resin bonded plywood. Cryogenics, 72, 90-102.

Kuo, J.F., Campbell, R.B., Hoie. S.M., Rinehart, A.J., Sandstrom, R.E., Yung, T.W., 2009. LNG tank sloshing assessment methodology - The new generation. International Journal of Offshore and Polar Engineering, 19, 241-253.

Moubarik, A., Pizzi, A., Allal, A., Charrier, F., Charrier, B., 2009.
Cornstarch and tannin in phenol-formaldehyde resins for plywood production. Industrial Crops and Products, 30, 188-193. Park, S.B., Lee, C.S., Choi, S.W., Kim, J.H., Bang, C.S., Lee, J.M., 2016. Polymeric foams for cryogenic temperature application: Temperature range for non-recovery and brittle-fracture of microstructure. Composite Structures, 136, 258-269.

Park, Y.I., Lee, J.H., 2018. Buckling strength of GTT NO96 LNG Carrier cargo containment system. Ocean Engineering, 154, 43-58.

Yang, C.G., Xu, L., Chen, N., 2007. Thermal expansion of polyurethane foam at low temperature. Energy Conversion and Management, 48, 481-485. 